\title{
Domestic Obligations concerning Monetary Stability
}

The Special Role of Central Banks

The second element of the emerging doctrine of Common Concern of Humankind, following the duty to cooperate, introduces the obligations at the domestic level or obligations to do homework. ${ }^{1}$ This element considers not only the duty to promote and protect the Common Concern at the local level but also the duty to implement the international commitments assumed in international agreements and in customary law. As stated by Cottier,

Common Concern of Humankind calls for action in domestic law and policy. It is at the heart of the principle and amounts to a key obligation under the doctrine of Common Concern of Humankind in order to offset the lack of reciprocity, to avoid free-riding and the endemic tragedy of the global commons (Hardin). The recognition of a problem as a common preoccupation entails the need to engage appropriate domestic resources and activities, again in accordance with equity and distributional justice and shared responsibility, to address the challenge. Think globally - act locally translates into domestic homework. ... Common Concern of Humankind is not limited to implementing international obligations by central government and institutions. Often, the main thrust will be measures undertaken upon own initiatives and bottom up. Depending on the problem and the public goods which need to be produced in response to the challenge, all layers of government may be involved. ${ }^{2}$

1 As explained in detail in chapter 3 of this book, the term 'homework' is introduced by the emerging doctrine as a legal denomination to encompass all the obligations that are attached to the principle of Common Concern of Humankind. For more detail on the normative components of the obligation to do homework as presented by the doctrine of Common Concern see, chapter 3 and Thomas Cottier, 'The Principle of Common Concern of Humankind' in Thomas Cottier (ed) 'The Prospects of Common Concern of Humankind in International Law' (CUP 2021).

2 ibid 63. 
Accordingly, by taking recourse to the doctrines of multilevel governance, Common Concern encourages timely and effective implementation of international commitments and promotes bottom-up initiatives to address the global challenges presented by the Common Concerns. Hence, the obligations to do homework comprehend two levels of commitment: the duty to promote and protect the Common Concern at the local level and the duty to implement international commitments assumed in international agreements and in customary law.

For the purposes of the potential Common Concern of monetary stability: the first level of commitment encompasses the pursuit and maintenance of monetary stability as a domestic public good and a local Common Concern. This is a clear sovereignty attribute and a state defines what is to be considered as monetary stability locally. The pursuit of monetary stability is usually entrusted to an independent central bank or the relevant monetary authority. Thus, this chapter studies the special role of central banks as the preferred institutional arrangement in the promotion and protection of monetary stability.

This section follows up and expands on the preliminary analysis made in chapter 2 of this book concerning the legal and institutional arrangements that promote monetary stability at the domestic level. ${ }^{3}$ Such promotion and protection of monetary stability have internal and external dimensions. While the 'internal dimension' of monetary stability refers to the stability of domestic prices (price stability), the 'external dimension' is understood as the stability of the value of a specific currency vis-à-vis other currencies (exchange rate stability).

Sainz de Vicuña, former general counsel of the European Central Bank (ЕСВ), remarks that 'The intrinsic or extrinsic values that a metal equivalent gave to money in the past have been replaced today by the surge of institutional frameworks destined to ensure the permanence over time of the purchasing power of money' ${ }^{4} \mathrm{He}$ also considers that 'there is a relationship between a currency internal purchasing power (that is, the capacity to acquire goods and services with prices denominated in the national currency), and its external

3 The legal and institutional arrangements to promote monetary stability at the domestic level are enshrined in the monetary sovereignty attributes of the states. See chapter 2 of this book.

4 Antonio Sainz de Vicuña, 'An Institutional Theory of Money' in Mario Giovanoli and Diego Devos (eds), International Monetary and Financial Law, The Global Crisis (oup 2010) 525. 
purchasing power (that is, acquisition of goods and services invoiced in a foreign currency). ${ }^{5}$

Consequently, it can be stated that in modern economies the value of money (or its purchasing power) relies fundamentally on the institutional framework. Therefore, decisions taken by domestic central banks or monetary authorities (through monetary and exchange rate policies) have a direct influence on the currency's purchasing power. Thus, this section starts by examining the institutional framework of central banking. In doing so it studies the main functions and objectives of central banks and monetary authorities in relation to monetary stability. The section continues by analysing the special characteristics of the system of exchange rate control and the management of a country's foreign reserves and its impact on exchange rate stability.

\subsection{Internal Dimension of Monetary Stability - Price Stability}

The design of the international monetary order in the post Bretton Woods era has preferred legal and institutional arrangements at the national level. Independent central banks have been the predominant institutional arrangement since the 199o's, playing a crucial role in the promotion and protection of monetary stability. ${ }^{6}$ Monetary policy decisions from major central banks have played a fundamental part in the response to the global financial crisis of 2007-2009 (GFC) and for the valuable role they played in this response central banks have been called the 'only game in town'.7

Proctor provides a functional definition of central bank stating that 'A central bank is an institution of a State. In the issue of money, the conduct of national monetary policy, the administration of a system of exchange control, and the management of a country's foreign reserves, it plainly discharges functions of a peculiar sovereign nature. 8 These central banks functions enumerated by

5 ibid.

6 There are other institutional arrangements for the promotion of monetary stability such as currency boards and legislated monetary rules. Rosa M Lastra, International Financial and Monetary Law (2nd edn, OUP 2015) 63-64.

7 Raghuram Rajan, 'The Only Game in Town' (2012) <www.project-syndicate.org/commentary/ the-limits-of-unconventional-monetary-policy-by-raghuram-rajan> accessed 21 October 2021; Mohamed El-Erian, The Only Game in Town: Central Banks, Instability, and Avoiding the Next Collapse (Random House, 2016), among others.

8 Charles Proctor, Mann on the Legal Aspect of Money (7th edn, oup 2012) 573. Proctor also remarks at page 571 that: It may be added that a central bank may have other functions. In some jurisdictions the central bank is responsible for the prudential supervision of the banking sector, whilst in other countries a separate agency is established for this purpose. But these additional features do not add to (or detract from) an entity's legal status as the central bank of a given country. 
Proctor have changed over time as acknowledged by the US court in the decision of NML Capital, Ltd. $v$ Banco Central de la Republica Argentina, in which it recognised 'that there is no definitive list of activities "normally understood" to be central banking functions. Indeed, the definition of what constitutes a "central bank activity" is likely to change over time. ${ }^{9}$ In this sense, Lastra states that, 'Nowadays the main rationale for central banking is the twin mandate of monetary stability and financial stability'.10

\subsubsection{Institution of a State}

Central banks as institutions of a state are usually established by law or statute which provides legitimacy to operate under a specific mandate. The mandate of a central bank is of a peculiar nature because of its special relationship with the government. As remarked by Lastra:

Central banks are at the centre, equidistant from the government and the financial system (they are both banker to the government and banker to the banks). Central banking is thus defined by the relationships of the central bank upwards with the government and downwards with the banking and financial system. The law must govern both relationships. ${ }^{11}$

Accordingly, central banks are both regulatory agencies and banks and consequently they carry out public functions governed by administrative law and commercial functions ruled by commercial law. ${ }^{12}$ As regulatory agencies most central banks around the world have been granted independence in the pursuit of monetary stability. ${ }^{13}$ This movement towards the granting of independence to central banks gained traction in the late 1980's and spread throughout the 199o's with the purpose of combating high inflation. Consequently and in pursuit of domestic price stability, states amended central bank laws to grant independence to central banks to control inflation. ${ }^{14}$ The International

$9 \quad$ NML Capital, Ltd.v Banco Central de la Republica Argentina $65^{2}$ F.3d 172, 175 (2nd Cir. 2011).

10 Lastra, International Financial and Monetary Law (n 6) 33.

11 ibid.

12 ibid.

13 The legal framework for the independence of central banks is explained in detail in Rosa M Lastra, Central Banking and Banking Regulation (Financial Markets Group LSE, 1996).

14 Lastra clarifies that: The phenomenon of independence is not unique to central banking. It is a feature inherent in the administrative law tradition in some countries where functional decentralization is considered an effective way of dividing power, often in combination with geographic decentralization, as is the case in the United States. The rise and rise of agencies or independent regulatory commissions can be explained because of the increasing intricacy of the functioning of the modern state. It is an effective way 
Monetary Fund (IMF or Fund), in the context of programs of reforms submitted by its member states, made these changes a necessary condition for such member state to access the Fund's financing. The Treaty on European Union (Maastricht Treaty) also made such changes a condition for a state's entry into the European Monetary Union (EMU).

The consensus that central bank independence is the preferred institutional arrangement was challenged by the expanded goals to be achieved by central banks and rising discontent with the 'status quo', which arose as a result of the GFC..$^{15}$ According to Goodhart and Lastra central bank legitimacy is built on the concept of sovereignty, which has two dimensions: formal and societal. The formal dimension rests on the democratic foundations of the central bank, usually established by law, treaty or constitution. The societal dimension depends upon the support given by the public to the existing system. Therefore, accountability becomes essential to safeguard the legitimacy of central banks over time. ${ }^{16}$

Central bank independence is not absolute but limited to the policy goals set by law, statute or treaty. Hence, central banks are granted independence from the government but at the same time they are accountable to this government. As pointed out by White 'In a democratically ordered society, no government agency, including the central bank, can be wholly "independent" from government'. ${ }^{17}$ Therefore, while independent central banks are entitled to

of dealing with the regulation of complex realities: money, securities, energy, transport, telecommunications, the environment and others. The skills, expertise and superior qualifications of technocrats (central bankers, energy regulators, etc.) compared to politicians reinforce the case for independence.

Rosa M Lastra 'Central Bank Independence and Financial Stability' (2010) 18 Revista de Estabilidad Financiera 49. On central bank independence also see Lastra (n 6) 6482; Geoffrey P Miller, 'An Interest Group Theory of Central Bank Independence' (1998) 27 Journal of Legal Studies 433; Douglas Arner and others, 'Central Banks and Central Bank Cooperation in the Global Financial System' (2010) 23.1 Pacific McGeorge Global Business \& Development Law Journal, 11; Forrest Capie and Geoffrey Wood, 'Central Bank Independence: Can it Survive a Crisis?' in (2013) 2 Rivista Di Storia Economica 193; Ferdinando Giugliano, Sam Fleming and Claire Jones, 'Central Banks: Peak Independence' Financial Times (London, 8 November 2015).

15 According to Goodhart and Lastra the rising discontent with the 'status quo' relates to the increase in populism, understood as 'a major disagreement with the central liberal tenet that allowing the free movement of labour, capital and goods and services between nations would be both generally beneficial and desirable in almost all circumstances'. Charles Goodhart and Rosa Lastra, 'Populism and Central Bank Independence' (2018) 29(1) Open Economies Review 49, 5 O.

16 ibid 54.

17 William R White, 'Speech' (Central Bank Governor's Club Meeting, Nafplio, 18 October 2012) < www.bis.org/speeches/spo21018.htm> accessed 21 October 2021. 
exercise their delegated powers with some degree of discretion in the pursuit of their mandates, they are still accountable to the government and to the electorate on the success or failure to achieve their mandates.

Accountability can take different forms, such as parliamentary accountability, judicial review and cooperation with the executive to coordinate policy. ${ }^{18}$ Lastra has pointed out that there are two types of accountabilities - ex-ante and ex-post accountability. An example of ex-ante accountability is where the executive or legislative branch of the government is involved in the appointment of central bank officials. On the other hand, reporting and appearances of central banks officials in front of the legislative branch are considered $e x$ post accountability. ${ }^{19}$ In addition, Lastra remarks that the accountability of independent central banks involves both a political dimension and a technical dimension..$^{20}$ The political dimension, usually stressed by lawyers, relates to the democratic and institutional legitimacy of independent agencies within the system of checks and balances among the different branches of the state (executive, legislative and judiciary). The technical dimension, mostly emphasised by economists, considers the efficient performance of the independent agencies' objectives and targets and the ex-post disclosure of their actions as a market-based form of accountability.

The judicial review of acts and decisions by central banks was scarce until the GFC. Most notably the Northern Rock case ${ }^{21}$ opened in UK the debate on

18 As remarked by Fischer, former vice chair of the Board of Governors of the Federal Reserve System: In almost all countries, the central bank's accountability is enforced by requiring regular reporting on monetary policy actions and outcomes to the legislature, to the executive branch, and to the public. The formal centerpiece of the required reporting is generally exercised by the regular publication and presentation to the legislature of an inflation report or monetary policy report, followed by public hearings on the report and related matters.

Stanley Fischer, 'Speech' (Herbert Stein Memorial Lecture National Economists Club, Washington DC, 2015) <www.federalreserve.gov/newsevents/speech/fischer20151104a. $\mathrm{htm}>$ accessed 21 October 2021.

19 Lastra (n 6) 9o. On the topic of accountable independence see Fabian Amtenbrink and Rosa M Lastra, 'Securing Democratic Accountability of Financial Regulatory Agencies A Theoretical Framework' in R V de Mulder (ed), Mitigating Risk in the Context of Safety and Security. How Relevant is a Rational Approach? (Rotterdam: Erasmus School of Law \& Research School for Safety and Security (OMV) 2008) 115.

$20 \quad$ Lastra (n 6) 90-92.

21 Northern Rock, a UK mortgage lender, received liquidity assistance from the Bank of England in September 2017 and this situation triggered a bank run that was followed by nationalisation of the entity and a series of legislative and regulatory responses in UK. Rosa M Lastra, 'Northern Rock, UK bank insolvency and cross-border bank insolvency' (2008) 9(3) Journal of Banking Regulation 165. 
discretion, financial stability and the moral hazard associated with the lender of last resort role of the Bank of England. Also, in the EU the Pringle case ${ }^{22}$ and the Gauweiler case ${ }^{23}$ dealt with the role of the Court of Justice of the European Union (CJEU) in the formation of economic and monetary policy. The Gauweiler case also considered the legality of an unconventional monetary policy measure (the Outright Monetary Transactions (омт) Programme). ${ }^{24}$ As clearly pointed out by Goodhart and Lastra:

Central bank discretion (a key component of independence) is the freedom to act within the limits of a legal framework. Judicial review does not extend to the 'content of the decision' (the aim of the Court is not to supplant or replace the decision taken or to second guess what central banks should have done), but it does extend to the parameters and legal framework that surround such decision in order to determine whether or not the central bank mandate has been exceeded. ${ }^{25}$

Additionally, the GFC brought to the forefront the issue of transparency of central bank policies, accompanying accountability. ${ }^{26}$ This new trend on greater transparency in relation to central bank policies aims to improve the success of the policies by enhancing communication mechanisms and providing clearer expectations for market participants. ${ }^{27}$ For example, the minutes of the

22 Case C-370/12 Thomas Pringle v Government of Ireland E U:C:2012:756.

23 Case C-62/14 Peter Gauweiler and Others $v$ Deutscher Bundestag EU:C:2015:40o.

24 The technical features of the омт were published in a press release in September 2012 but were never implemented. European Central Bank, 'Technical Features of Outright Monetary Transactions' (6 September 2012) <www.ecb.int/press/pr/date/2012/html/ pri209o6_1.en.html> accessed 21 October 2021. The legality of this programme was questioned by German citizens in the German Constitutional Court and the case was brought to the CJEU for a preliminary ruling. On 16 June 2015 the CJEU issued its final ruling that the conditional омт programme was legal on the basis that the Есв has not exceeded its power concerning monetary policy and did not violate the monetary financing prohibition on EU nations. Case C-62/14 Peter Gauweiler and Others v Deutscher Bundestag ibid.

25 Goodhart and Lastra (n 15) 63.

26 A study by Dincer and Eichengreen established a significant movement towards greater central bank transparency in the last decade and also considered that transparent monetary policies are more likely in democratic countries. Nergiz Dincer and Barry Eichengreen, 'Central Bank Transparency: Causes, Consequences and Updates' (2009) NBER Working Paper No $14791<$ www.nber.org/papers/w14791> accessed 21 October 2021.

27 Kaufmann and Weber also pointed out that enhanced transparency in relation to central bank policy relates to democratic accountability and thus, is a mechanism to balance central bank independence. Christine Kaufmann and Rolf H Weber, 'Transparency and Monetary Affairs' in Thomas Cottier and others (eds), The Rule of Law in Monetary Affairs (CUP 2014) 467. 
Federal Open Market Committee in the United States of America (US) ${ }^{28}$ and the minutes of the Monetary Policy Committee of the Bank of England in the United Kingdom $(\mathrm{UK})^{29}$ must be published within a certain time frame. Also, in its efforts to increase transparency the Есв decided to start publishing an account of the Governing Council's monetary policy meetings minutes since the beginning of 2015 , but it does not divulge the details of the vote's records. ${ }^{30}$

\subsubsection{Issuance of Money}

States exercise monetary sovereignty in the issuance and regulation of money according to the law of the currency (lex monetae), which defines what money is and the nominal value that money has in a particular jurisdiction. Hence money, as a creation of the law, is territorial and must be studied within a legal system. The 'state theory of money', adopted in most modern constitutions, claims that money is what the law of the states dictate it to be and as a result falls within the jurisdiction of the issuing state. ${ }^{31}$

The law usually entrusts the central bank with the function of note issuance as a monopoly in the given jurisdiction. ${ }^{32}$ In monetary unions this function of note issuance is transferred by treaty from the national authorities of the member states to the supranational authorities of the union, comprising a common central bank or monetary authority. ${ }^{33}$ Hence, it can be stated that the legal and institutional arrangements of central banks are at the centre of monetary affairs. Sainz de Vicuña asserts that,

the concept of money, in a situation of global markets and modern communication technologies, is now inseparable from the institutional set-up of the central banks (that is, their independence, mandate, and instrumentaria) and from the normative framework under which central

28 Federal Reserve Act, s 10 (12 U.S.C. 226).

29 Bank of England Act 1998, s 15.

30 Claire Jones, 'European Central Bank to publish account of meetings' Financial Times (Frankfurt, 18 December 2014).

31 For a more detailed analysis on monetary sovereignty and the 'state theory of money' see chapter 2, section 2 of this book.

32 While the monopoly of note issuance by the central bank is the predominant arrangement, there are other arrangements with different levels of competition. Lastra provides a list of some theoretical scenarios of commercial banks competing in the issuance of money. Lastra, Central Banking and Banking Regulation (n 13). Also, as remarked in chapter 2 , section 2 , the expansion of virtual currencies brings some competition to the provision of currency.

33 In the case of the EMU the issuance of money and the conduct of monetary and exchange rate policies has been transferred from national authorities to the European System of Central Banks (ЕSСв) that includes the Есв and the national central banks. 
banks, credit institutions, financial infrastructures (for example, payments systems), and markets operate, which ensures the stability and the functionality of money. ${ }^{34}$

Central banks, having this monopolist function, can control the volume of the fiat money ${ }^{35}$ in circulation and also its seigniorage (that is, the face value of the money minus the cost of their production). The fiat money (physical bank notes and coins) in circulation is legal tender as defined by the legislators of the specific monetary system. Proctor remarks that 'only physical money is legal tender, whilst the expression "money" embraces a much wider variety of instruments.' ${ }^{36}$

The functions of money as a measure of value, a store of value and a means of payment have evolved over time. For example, during the Bretton Wood system of 1940's the value of money was attached to the value of physical goods (metals, such as gold and silver) and since the collapse of the system in the early 1970's the value of money has been determined by the monetary policy of the relevant central bank and market conditions. The use of fiat money (or cash) as a means of payment has also changed with a decrease in the use of cash over scriptural money. That is, cash payments are used mostly in small amounts while large amounts are settled with scriptural money. ${ }^{37}$

Money issued by a central bank entails a legal claim against it. That is, a credit against a central bank in its deposit account or in cash. As explained by Sainz de Vicuña, 'Money created by central banks is therefore a liability that appears on their balance sheets. It consists of the central bank's duty as deposit-taker to allow the deposit-holder (that is, the commercial banks) to withdraw amounts by way of transfer or cash withdrawal (that is, stock of banknotes)'. ${ }^{38}$ He continued by stating that:

Money is also the credit balance of sight deposits made by the public with credit institutions. These have also the legal nature of being claims against a bank, in this case a commercial bank, but are considered

34 Sainz de Vicuña (n 4) 523.

35 Fiat money is defined as 'Paper money or coins of little or no intrinsic value in themselves and not convertible into gold or silver, but made legal tender by fiat (order) of the government'. Financial Times Lexicon <http://lexicon.ft.com/Term?term=fiat-money $>$ accessed 21 October 2021.

$36 \quad$ Proctor $(\mathrm{n} 8) 74$, fn 51 .

37 Scriptural money is dematerialised money such as credit cards, debit cards, online debits, e-money, bank transfers, cheques, computer money (eg paypal), among others. 
'money' because such claims can be transformed on demand into banknotes, that is, into claims against the central banks. ${ }^{39}$

Consequently, Sainz de Vicuña noted that there is a difference between what is called by the economists 'central bank money' and 'commercial bank money'. ${ }^{40}$ While the former entails a central bank liability the latter represents a commercial bank liability. ${ }^{41}$

This note issuance function together with the fractional reserve basis under which most commercial banks operate are the reasons for the lender of last resort' (LOLR) function of central banks. ${ }^{42}$ In a fractional reserve system only a portion of a bank's assets are liquid. Consequently, banks are not able to convert all of their assets into cash at the same time without losing value or selling them at fire-sale price. This characteristic of a bank's balance sheet makes it fragile to confront a massive liquidity crisis. The central banks, having monopoly of note issuance, are ultimate providers of high-powered money and are

39 ibid.

40 McLeay and others pointed out that, 'Although commercial banks create money through lending, they cannot do so freely without limit. Banks are limited in how much they can lend if they are to remain profitable in a competitive banking system'. Michael McLeay, Amar Radia and Ryland Thomas, 'Money Creation in the Modern Economy' (Bank of England Quarterly Bulletin, 2014 Q1) <www.bankofengland.co.uk/-/media/boe/files/ quarterly-bulletin/2014/money-creation-in-the-modern-economy.pdf > accessed 21 October 2021 .

41 ibid 524. According to the Oxford Dictionary of Finance and Banking a commercial bank refers to: A privately owned bank that provides a wide range of financial services, both to the general public and to firms. The principal activities are operating cheque current accounts, receiving deposits, taking in and paying out notes and coin, and making loans. Additional services include trustee and executor facilities, the supply of foreign currency, the purchase and sale of securities, insurance, a credit-card system, and personal pensions. They also compete with the finance houses and merchant banks by providing venture capital and with building societies by providing mortgages.

Jonathan Law and John Smullen (eds), A Dictionary of Finance and Banking (4 rev ed, OUP 2008).

42 Sir Francis Barings was the first to give the name 'the denier resort' to the Bank of England at the end of the eighteenth century. Barings also pointed out that the Bank of England was the only bank that could provide liquidity in times of crisis to the rest of the banks of the system. During the nineteenth century the notion of the LOLR was the focus of much doctrinal debate. From that period, the most relevant writings on the matter emerged from the hands of Thornton in 1802 and Bagehot in 1873. Their contributions, together with those of other scholars of the epoch, have helped to give clarity to the doctrine, improve and detail the main principles and conditions to grant the LOLR assistance either to the market or to individual institutions. Thomas M Humphrey and Robert E Keleher, 'The Lender of Last Resort: A Historical Perspective' (1984) 4(1) Cato Journal 275. 
given the final responsibility to ensure the convertibility of a bank's assets into cash. ${ }^{43}$

The fractional reserve banking system under which most commercial banks operate and create the so-called 'commercial bank money' has been subject to a long-standing criticism that acquired new relevance in the aftermath of the GFC and more recently in the debate on the 'Vollgeld' or 'sovereign money' referendum held and rejected in Switzerland on 10 June $2018 .{ }^{44}$ The advocates of this referendum proposed a radical reform which purpose was to prohibit commercial banks from issuing commercial money through their traditional business model and to reinstate the central bank as the monopolist provider of all the money in circulation in the given jurisdiction.

\subsubsection{Privately Issued Virtual Currencies and Central Bank Issued Virtual Currencies}

Other topics that acquired relevance recently in relation to the provision of currency are the proliferation of privately issued virtual or digital currencies (VCs) and the proposals concerning central bank issued virtual or digital currencies (CBVC). Although VCs and CBVCs have common features mostly related to technology - in particular distributed ledgers technology (DLT) and blockchain technology - they are not the same and must be differentiated. ${ }^{45}$ While privately issued vcs are 'digital representations of value, issued

43 The GFC has proved that the LOLR remains a vital notion for the central banks in the prevention and management of crises. For a comprehensive description of this notion see Andrew Campbell and Rosa M Lastra, 'Revisiting the Lender of Last Resort' (2009) 24 BFLR 453 .

44 Ralph Atkins, 'Radical reform: Switzerland to vote on banking overhaul' Financial Times (Bern, 29 May 2018); Martin Sandbu, 'Treat money as the public good it is' Financial Times (31 May 2018); Martin Wolf, 'Why the Swiss should vote for "Vollgeld"' Financial Times (6 June 2018).

45 Hileman and Rauchs conducted a recent benchmark study on the use of blockchain and DLT and in an effort to clarify the concepts they stated that: the term 'distributed ledger technology' refers to all initiatives and projects that are building systems to enable the shared control over the evolution of data without a central party, with individual systems referred to as 'distributed ledgers'. If one wants to describe a system that has global data diffusion and/or uses a data structure of chained blocks, one should call it a 'blockchain'.

Garrick Hileman and Michel Rauchs, 'Global Blockchain Benchmarking Study' (Cambridge Centre for Alternative Finance 2017) <https://www.jbs.cam.ac.uk/facultyresearch/centres/alternative-finance/publications/global-blockchain/\#.YXDW157mhdg> accessed 21 October 2021. 
by private developers and denominated in their own unit of account, ${ }^{\prime 6}$ central bank issued CBVC s respond to recent proposals to 'address the direct challenge posed by privately issued vcs by increasing the functionality of central bank money and bolstering public confidence in central bank money',47 among other considerations.

Lastra and Allen, in a recent paper requested by the European Parliament's Committee on Economic and Monetary Affairs, provide an assessment of the legal aspects of VCs and the implications for central banks' monetary policy and monopoly of note issue. ${ }^{48}$ The authors start by considering vC s as financial hybrids that do not fit within established legal concepts but can be differentiated from other types of financial instruments mostly by:

(i) their use of DLT (in particular blockchain data structures) to facilitate peer-to-peer exchange; (ii) their issuance by an entity outside the traditional monetary system of central banks, commercial banks, and licensed financial intermediaries; (iii) their denomination in a novel unit of account rather than a fiat monetary unit. ${ }^{49}$

These unique characteristics of vcs are a source of concern for regulators worldwide. A variety of regulatory responses have emerged in different jurisdictions and most focus on addressing some of the risks associated with vCs (such as financial integrity, tax evasion and consumer protection). These responses range from the prohibition on usage of vCs, clarifications of existing laws and regulations to consumer warnings. ${ }^{50}$ There are also concerns at the international level because vcs operate globally. ${ }^{51}$ Thus, a coordinated and

46 Dong He and others, 'Virtual Currencies and Beyond: Initial Considerations' (2016) IMF Staff Discussion Note 16/o3, 7 <www.imf.org/external/pubs/ft/sdn/2016/sdn16o3.pdf> accessed 21 October 2021.

47 Rosa Maria Lastra and Jason Grant Allen, 'Virtual Currencies in the Eurosystem: challenges ahead' (European Parliament Monetary Dialogue, July 2018) <https://www.europarl.eur opa.eu/cmsdata/150541/DIW_FINAL\%2opublication.pdf> accessed 21 October 2021.

48 ibid.

49 ibid 11.

50 An IMF Staff Discussion Note of 2016 includes in its annex a comparison of the different regulatory approaches to vCs opted by a selection of jurisdictions. Dong He and others (n 46).

51 Dong He and others remark that: Regulatory responses are also being developed at the international level. International efforts have focused on achieving consensus on the potential benefits and risks of VC s and identifying areas for future cooperation. A number of international bodies have both provided a forum to discuss issues related to VCs and contributed to the debate through the issuance of reports, guidance and manuals in their areas of expertise. Dong He and others (n 46) 26. 
consistent regulatory approach to vCs will be preferable to avoid regulatory arbitrage. However, most jurisdictions have adopted a 'wait and see' strategy in order not to stifle beneficial innovation while the vcs market develops.

Lastra and Allen consider that this 'wait and see' policy strategy is rightly justified on the grounds that vCs do not currently pose any significant implications for the central banks' role on money creation and monetary policy. ${ }^{52}$ Some vCs tout that they offer an alternative form of currency in direct competition to the conventional monetary system. However, the authors consider that the growing demand for VCs is motivated more by the interest to invest in a new form of unconventional speculative asset rather than by the desire to obtain a currency substitute outside the traditional monetary system. This consideration together with the current fact that the use of vcs as a medium of exchange (or means of payment) is very low and that vc s possess several technical limitations in their 'medium of exchange' function to qualify as 'money status', weakens the VCs as a potential threat to the central banks' control over money supply. Nonetheless, the authors remarked that this 'wait and see' policy approach to vCs must be regularly re-evaluated to consider new developments in the area. ${ }^{53}$

A recent paper by the Bank for International Payments (BIS) highlighted that CBVC s are 'potentially a new form of digital central bank money that can be distinguished from reserves or settlement balances held by commercial banks at central banks. ${ }^{54}$ Lastra and Allen also reflected on the proposals on the issuance of $\mathrm{CBVCs}$ and considered that there are three central reasons for central banks to choose to issue a CBVC:

The first, and most obvious reason, is that the use of cash is declining in many jurisdictions as electronic payment methods have become more safe and convenient. ... The second reason is that central banks currently provide extensive settlement and clearing services for commercial banks, and a CBVC could be used to increase the efficiency of this service with significant costs savings. ... The third reason relates to extending central

$5^{2} \quad$ Lastra and Allen (n 47).

53 Lastra and Allen conclude that 'If the vc market continues to grow, central banks such as the Есв may face challenges in their monetary policy role as a large category of moneylike payment instruments would be out of their oversight and control'. Lastra and Allen (n 47) 46.

54 BIS Committee on Payments and Market Infrastructures, 'Central bank digital currencies' (March 2018) <www.bis.org/cpmi/publ/d174.pdf> accessed 21 October 2021. 
banks' monetary policy toolkit. In particular, CBVC could potentially solve the 'zero lower bound' ('ZLB') problem to encourage spending in the economy during periods of downturn. ${ }^{55}$

These authors continued by stressing that any proposed СBVC will have an effect on the existing monetary system that will vary depending on the choice of design of the instrument. The BIS paper classifies the design choices for a CBVC according to 'access (widely vs restricted); degree of anonymity (ranging from complete to none); operational availability (ranging from current opening hours to 24 hours a day and seven days a week); and interest bearing characteristics (yes or no), ${ }^{56}$ Recognising that many forms of сBVCs are possible, the BIS paper studies two key alternatives. The first one is titled the wholesale alternative because access to CBVC s would be limited to a specific group. The second option is named the general purpose alternative because access to CBVC s would be unlimited.

The key properties in the design of a CBVC will have different implications not only on the payments system but also on monetary policy and the stability of the financial system. Therefore, the BIS paper stressed that:

Any steps towards the possible launch of a СвDC should be subject to careful and thorough consideration. Further research on the possible effects on interest rates, the structure of intermediation, financial stability and financial supervision is warranted. The effects on movements in exchange rates and other asset prices remain largely unknown and also deserve further exploration. ${ }^{57}$

From all the considerations expressed above it can be stated that both vCs and СвVC s present possibilities and threats to the current design of the international monetary and financial order. More remarkably the rise of new technologies like DLT and blockchain structure has the potential to improve existing mechanisms such as the payment, clearing and settlement systems. Hence, regulators must closely monitor the developments in the area while taking care not to stifle beneficial innovation. ${ }^{58}$

$55 \quad$ Lastra and Allen (n 47) 39.

56 BIS (n 54) 1 .

57 ibid 2.

$5^{8}$ As stated by He, There are both challenges and opportunities for central banks in the digital age. Central banks must maintain the public's trust in fiat currencies and stay in the game in a digital, sharing, and decentralized service economy. They can remain relevant 


\subsubsection{Conduct of National Monetary Policy}

National monetary policy, an essential element of the economic policy of the State, is frequently conducted by a central bank or monetary authority which usually is independent from the government. ${ }^{59}$ Most central bank laws assign the central bank with the monetary policy function, listing its objectives and instruments, but do not provide a legal definition of the term. However, it can be stated that 'Monetary policy involves control over the supply of money within the economy and the cost of borrowing that money in terms of its interest rate' ${ }^{60}$ Consequently Gianviti explained the consequences of the implementation of monetary policy as follows, 'The expansion or contraction of the money supply will affect prices. The cost of credit, which affects the level of consumption and investment, varies with the volume of the money supply and with the cost of money available for loans' ${ }^{61}$

The conduct of monetary policy is directed and also constrained by the objectives or goals set in the central bank's mandate. According to Lastra, 'In the context of the rules versus discretion monetary debate, it is interesting that the advent of central bank independence granted a substantial degree of discretion (technical, not political) to central bankers within the realm of their legal mandate to strive for monetary stability'. ${ }^{62}$ These goals are usually determined by the central bank's statute or treaty. In some cases, such as the US Federal Reserve System, central banks are conferred an additional discretion in selecting the objectives to pursue.

The mandate goals of the central banks are generally domestic objectives to pursue the common good. As acknowledged by Gianviti:

Most countries officially recognise that preserving the value of money is a desirable objective, a 'public good', which has to be attained and preserved to achieve real growth. What this entails, however, is not uniformly

by providing more stable units of account than crypto assets and by making central bank money attractive as a medium of exchange in the digital economy.

Dong He, 'Monetary Policy in the Digital Age: Crypto assets may one day reduce demand for central bank money' (2018) 55(2) Finance \& Development 13, 16.

Independent central banks are in charge of both formulation and implementation of monetary policy. Dependent central banks only deal with the implementation of monetary policy, with the central government retaining control over the design of the policy.

6o Proctor (n 8) 94 .

61 François Gianviti, 'Relationship Between Monetary Policy and Exchange Rate Policy' in Cottier and others (eds), The Rule of Law in Monetary Affairs (CUP 2014) 545.

62 Rosa M Lastra, 'The Role of Central Banks in Monetary Affairs: A Comparative Perspective' in Cottier and others (eds), The Rule of Law in Monetary Affairs (CUP 2O14) 91. 
understood. Between preserving the value of the currency in terms of one or more foreign currencies and preserving it in terms of domestic prices, a choice has to be made. ${ }^{63}$

Since the 199o's the objective of domestic price stability prevailed over others in most central bank laws. For example, the EsCB's 'primary objective ... shall be to maintain price stability',64 the Fed, to 'promote ... stable prices' ${ }^{\prime 65}$ and the Bank of England, 'to maintain price stability' ${ }^{\prime 6}$ Lastra explains that the price stability objective of central banks acquired relevance in the early 199o's as a response to the inflationary conditions of the 1970's and 1980's. She also explains that this objective is backed by economic theory focused on keeping inflation under control and on the empirical proof that independent central banks can control inflationary scenarios better than politicians. ${ }^{67} \mathrm{~A}$ standard definition of inflation is 'A general increase in prices in an economy and consequent fall in the purchasing value of money' ${ }^{68}$ However, domestic price instability can come both from increasing prices (inflation) and decreasing prices (deflation). Thus, White considers that 'there is a growing recognition that "price stability" as an objective of policy implies resisting both rising and falling prices' 69

The prevailing goal of domestic price stability on central banks mandates follows the 'Tinbergen Rule. ${ }^{70}$ As explained in chapter 2, this economic rule relies on the assumption that each policy objective correlates to a policy instrument. Hence, multiple policy objectives should be achieved with multiple instruments otherwise some of the objectives will be missed out or under achieved. That said, this rule is applied by central banks (one institution) in the implementation of monetary policy (one instrument) for the pursuit of monetary stability (one goal).

The Tinbergen Rule worked very well for monetary affairs for a long period and helped successfully to contain inflation. However, this rule presented some fissures. For example, in the context of deflation increasing prices are

\footnotetext{
63 Gianviti (n 61) 568.

64 Treaty on the Functioning of the European Union [2008] oJ C115/47 Art 127 and Protocol (No 4) on the Statute of the European System of Central Banks and of the Есв [2010] OJ $\mathrm{C}_{326 / 230}$ Art 2.

6512 US Code 226Federal Reserve Act, Section 2 A.

66 Bank of England Act 1998, s 11.

67 Lastra (n 6) 56-59.

68 Oxford Dictionary of Finance and Banking (n 41).

69 White (n 17).

70 Jan Tinbergen, On the Theory of Economic Policy (North Holland Pub Co 1952).
} 
not a concern (e.g. the case of Japan $)^{71}$ and in the context of the most recent GFC the central banks have moved their main concern from price stability to financial stability. ${ }^{72}$ With the expanded objectives (financial stability, growth, employment) central banks resorted to a new series of instruments to achieve them. Hence, since the beginning of the GFC central banks have resorted not only to conventional monetary policy instruments (like changes in the interest rate policies) but also unconventional monetary policy instruments. These unconventional tools comprise 'credit support, credit easing, interventions in foreign exchange and securities markets, provision of liquidity in foreign currency and quantitative easing $(\mathrm{QE}) \cdot{ }^{73}$

The expanded goals of central banks together with the recourse to unconventional monetary policies have been subject to much debate and scrutiny since the start of the GFC. The discussion is mainly concerned with the legality of the expansion of central bank mandates and the limits of their emergency powers. In this context, the 'rules versus discretion' debate in monetary affairs regained relevance because central banks have discretionary powers within a legal framework. ${ }^{74}$ Goodhart and Lastra remind us that:

71 'The Japanese economy has experienced weak inflation for most of the past two decades. ... Continued efforts to reflate the economy have so far fallen short, highlighting the difficulty in escaping a deflation trap once expectations are anchored around a deflation equilibrium'. Samya Beidas-Strom and others, 'Global Disinflation in an Era of Constrained Monetary Policy' in World Economic Outlook (IMF 2016) <www.imf.org/ en/Publications/WEO/Issues/2016/12/31/Subdued-Demand-Symptoms-and-Remedies > accessed 21 October 2021.

72 The rediscovered objective of financial stability and also the concerns about growth and employment during the GFC triggered regulatory changes for mandates of central banks. For example, in the US, the Dodd Frank Act 2010 reinforced the mandate of financial stability of the Federal Reserve System. In the UK, the law governing the Bank of England was changed to include financial stability together with monetary stability as a dual mandate. In the EU, despite monetary stability remaining as the primary objective in the Treaty, the mandate of the ЕСв has been expanded through secondary law during the GFC and a new 'banking union' is underway. For a detailed explanation of these regulatory changes and the rediscovered objective of financial stability see Lastra (n 6) 29-110; Rosa M Lastra and Charles E Goodhart, 'Interaction Between Monetary Policy and Bank Regulation' (Monetary Dialogue, September 2015) <www.europarl.europa.eu/committees/en/econ/ monetary-dialogue.html?id=20150914CPUo5481 > accessed 21 October 2021.

73 Lastra (n 6 ) 1-42. For more detail on conventional and unconventional monetary policies see chapter 2 of this book.

74 This consideration was reflected in the famous statements made by Ben Bernanke, former chairman of the Fed, 'the Federal Reserve has done, and will continue to do, everything possible within the limits of its authority to assist in restoring our nation to financial stability and economic prosperity ...' and by Mario Draghi, president of the Есв, 'Within our mandate, the Есв is ready to do whatever it takes to preserve the euro. And believe me, 
Discretion of course should not mean arbitrariness. It means freedom to act (or not to act) within a framework of rules; and the rules can be changed. ... Some argue that the rules that frame the discretionary decision should be further enhanced. However, it is important to preserve the flexibility to act swiftly in a crisis. ${ }^{75}$

Moreover, the debate concerning central banks mandates and the limits of their emergency powers in crises times have also raised the discussion about the contours between monetary policy and fiscal policy. This debate about the contours among the two policies is not new but has been renewed in the post GFC era and, especially, during the coronavirus disease pandemic (COVID-19) crisis. $^{76}$

According to the 'Annual Economic Report 2020'77 published by the BIS, monetary and fiscal policies have been very effective since the start of the COVID-19 crisis. As remarked by Borio, "They rightly worked in close concert leveraging their comparative advantage. Monetary policy deployed its power to create and distribute liquidity; fiscal policy its power to transfer resources and spend. Together, they prevented a much deeper contraction and laid the basis for the recovery' ${ }^{\prime 8}$ Borio also states that while blurring the lines among the policies was necessary to provide an effective response to the COVID-19 crisis, it is also relevant to reaffirm the clear boundaries between monetary and fiscal

it will be enough'. Ben S Bernanke, 'Speech' (National Press Club Luncheon, Washington, 18 February 2009) <www.federalreserve.gov/newsevents/speech/bernanke20o9o218a. htm > accessed 21 October 2021; Mario Draghi, 'Speech' (Global Investment Conference, London, 26 July 2012) <www.ecb.europa.eu/press/key/date/2012/html/sp120726.en.html> accessed 21 October 2021.

75 Goodhart and Lastra (n 15$) 60$.

76 The Covid-19 crisis started in Asia in late 2019 and quickly expanded throughout the rest of the world. As the health crisis worsened, the economic and social crisis also deepened. Equity and credit markets plummeted until major central banks and monetary authorities started injecting liquidity to signal their strong support. See for example Stanley White, Terje Solsvik, Jonnelle Marte, 'Central banks flash the cash as market panic drives liquidity squeeze' Reuters (Hong Kong, London, New York, 13 March 2020) <https://www .reuters.com/article/health-coronavirus-liquidity/central-banks-flash-the-cash-as-mar ket-panic-drives-liquidity-squeeze-idINKBN210oNV? edition-redirect=in $>$ accessed 21 October 2021.

77 BIS, 'Annual Economic Report 2020', chapters I and II, <https://www.bis.org/publ/arpdf/ ar2O20e.htm> accessed 21 October 2021.

78 Claudio Borio, 'Speech: Monetary and fiscal policies at a crossroads: New Normal or New Path?' (2021), Panel remarks at Latvijas Banka Economic Conference, <https://www.bis .org/speeches/sp210920.pdf > accessed 21 October 2021. 
policies once the COVID-19 crisis has been left behind and the macroeconomic conditions allow.

\subsection{External Dimension of Monetary Stability - Exchange Rate Stability}

The external dimension of domestic monetary stability - understood as the stability of the value of a specific currency vis-à-vis other currencies (exchange rate stability) - is considered to be part of the foreign exchange policy of a country. Foreign exchange policy encompasses not only the determination of the exchange rate in a given jurisdiction but also the choice of the exchange regime and the management of the reserve assets (monetary reserves). Given these particularities of the foreign exchange policy, the responsibilities of the government and those of the central bank or monetary authority can be confused. Hence, Lastra pointed out that:

the dividing line of what constitutes foreign exchange policy is often a fuzzy one. In any case, responsibility for the formulation of the exchange rate policy usually rests with the government, while responsibility for its implementation is generally entrusted to the central bank. Accordingly, the central bank has traditionally conducted operations in foreign exchange markets to sustain the national currency's external value, following the guidelines set by the government. ${ }^{79}$

Notwithstanding the major involvement of the government in the direction of the foreign exchange policy, the role of the central bank in this dimension is still crucial. The main reason for this is that nowadays the internal dimension (price stability) and external dimension (exchange rate stability) of monetary stability are intrinsically interrelated. As observed by Gianviti:

Although the conduct of a country's monetary policy is guided essentially by domestic objectives, such as price stability and/or economic growth and full employment, some decisions may be guided by exchange rate considerations. ... Conversely, in the conduct of a country's exchange rate policy, some decisions may be guided by monetary policy considerations. ${ }^{80}$

\footnotetext{
$79 \quad$ Lastra (n 6) 51.

8o $\quad$ Gianviti (n 61) 546 .
} 
To illustrate the interrelation between monetary policy and exchange rate policy Gianviti described two possible scenarios. ${ }^{81}$ In the first case he mentioned the use of instruments of monetary policy to pursue exchange rate stability. That is, for example, a central bank increasing the interest rate for its loans to commercial banks and imposing higher reserve requirements for the extension of credit in order to prevent a depreciation of the exchange rate and to prevent capital outflows. ${ }^{82}$ The second case mentioned by Gianviti is the use of exchange rate policy for price stability purposes. That is, for example, a central bank buying all incoming foreign exchange to increase the monetary base and reduce a large balance of payments surplus in the country.

Despite the beneficial effects of coordination between monetary and exchange rate policies, Gianviti also pointed out that these internal and the external dimensions of monetary stability pursue different objectives that can be incompatible in the medium and long term. ${ }^{83}$ This conflict between policies was recognised in the text of the Treaty establishing the European Community (EC Treaty) and incorporated later in the Consolidated Version of the Treaty on the Functioning of the European (TFEU). The TFEU provides that the Council can agree on an exchange rate system for non-community currencies subject to a previous recommendation or consultation with the ЕСв 'in an endeavour to reach a consensus consistent with the objective of price stability .... ${ }^{84}$

$81 \quad$ ibid.

82 This scenario presented by Gianviti was experienced by Argentina during the first week of May 2018 mainly because of the pressure on the Argentinean Peso inflicted by a combination of higher US interest rates, the strong US Dollar and an ongoing domestic conflict with regard to a new legislation to increase the tariff on public services. In order to prevent deeper currency depreciation and capital outflows Argentina's central bank raised the key borrowing rate from $27.25 \%$ to $40 \%$. Cat Rutter Pooley and others, 'Argentina Stuns Markets as it pushes interest rates to 40\%' Financial Times (London, 5 May 2018); John Authers, 'Strong Dollar Poses Big Threat for Emerging Market Investors' Financial Times (5 May 2018).

83 See François Gianviti, 'The Objectives of Central Banks' in Mario Giovanoli and Diego Devos (eds), International Monetary and Financial Law, The Global Crisis (oup 2010) 468. On the conflict between monetary and exchange rate policies also see, Manuel Guitián, 'Rules or Discretion in Monetary Policy: National and International Perspectives' in Tomás J T Baliño and Carlo Cottarelli (eds), Frameworks for Monetary Stability: Policy Issues and Country Experiences (International Monetary Fund 1994) 33.

84 Consolidated Version of the Treaty establishing the European Community [2002] OJ $\mathrm{C}_{325 / 33}$ Art 111(1). This provision has been incorporated as Art 219(1) of the Consolidated Version of the Treaty on the Functioning of the European Union oJ C115/47 (TFEU). 


\subsection{1}

Administration of a System of Exchange Control

Countries are free to choose from different exchange rate regimes or arrangements. Since the collapse of the 'fixed exchange rates' system promoted by the Bretton Woods System of 1944 and the subsequent enactment of the Second Amendment to the Articles of Agreement ${ }^{85}$ of the IMF in 1978 the era of 'floating exchange rates' began. ${ }^{86}$ Countries can choose from a variety of arrangements that include free floating and floating regimes, pegging exchange rates to one currency or to a basket of currencies, using the currency of another state and participating in a currency bloc arrangement.

Notwithstanding the choice of the exchange rate regime Lastra considers that:

The reality of exchange markets is that exchange rates do fluctuate. Under a system of flexible exchange rates, such variations (appreciation or depreciation of the currency vis-à-vis other currencies) are triggered by market forces. Under a system of government controlled exchange rates, such variations (devaluation or revaluation) are officially imposed decisions. ${ }^{87}$

Concurring with Lastra, Proctor adds that in the era of floating exchange rates the value of a currency in terms of another can be measured in two ways - par of exchange (nominal) and the rate of exchange (real). The par of exchange (nominal) 'is the equation between two money units, each based on a fixed (usually metallic) standard'.88 This measure is no longer in use since the abandonment of the 'par-value regime' (each currency had a par value with gold or

85 As noted by Sir Joseph Gold in 1984: The outstanding characteristic of the provisions on exchange rates in the Second Amendment is that there is no insistence on a unified regime. Each member is free to choose its exchange arrangement, with the exception that a member may not maintain the external value of its currency in terms of gold. A member is free also to determine the external value of its currency under the chosen exchange arrangement.

Joseph Gold, 'Public International Law in the International Monetary System' (1984) 38 Sw LJ 819 (emphases added).

86 Notwithstanding this total freedom in the choice of their exchange rate regime the new Article IV, section 1 of the Articles of Agreement of the IMF (Articles of Agreement) created obligations on the conduct of members' policies with the intention to promote exchange rate stability. See IMF, 'Articles of Agreement of the International Monetary Fund' < www.imf.org/external/pubs/ft/aa/index.htm > accessed 21 October 2021. For more detail see chapter 1 section 3 of this book.

87 Lastra (n 6) 425 .

88 Proctor (n 8) 495. 
with the US gold dollar standard) of the Bretton Woods System of 1944. The rate of exchange (real) refers to the 'market rate' being 'The most frequently quoted rate of exchange is the spot rate, which involves immediate delivery of the currency concerned by means of a credit to the account of the buyer or to its owner'.89

Although market forces - ruled by the law of offer and demand - determine the 'market rate' of a currency in relation to another currency, governments retain control over the administration of the system of exchange control and the determination of exchange rate in the given country. The administration of the system of exchange control is not an exclusive function of the central bank and, as mentioned before, usually the central bank implements an exchange rate policy that is decided by the government. ${ }^{90}$

A system of exchange control is usually conducted through domestic regulations that include limitations on capital transfers and/or international payments as artificial boundaries aimed at the protection of national credit markets. ${ }^{91}$ While capital transfers relate to the 'capital account' of a country, international payments relate to the 'current account' of a country. As explained in chapter 1 of this book, states are free to adopt 'capital account' restrictions but the rules of international law pose some limitations on 'current account' restrictions. The following chapter 6 detailed the different types of exchange restrictions and capital controls and their corresponding rationales.

\subsubsection{Management of a Country's Foreign Reserves}

As defined in chapter 1 of this book, the term 'reserve assets' refers to 'external assets that are readily available to and controlled by monetary authorities for meeting balance of payments financing needs, for intervention in exchange markets to affect the currency exchange rate, and for other related purposes ....92 This definition explains the economic foundation for countries in holding foreign reserves. That is, exchange rate stability (for both appreciation and depreciation episodes), trade financing and servicing of the country's debts.

89 ibid 503. Proctor also clarifies that the market or commercial rate is not an official rate, which is why commercial documents that involve an exchange rate transaction should detail the institution whose rate is to be referred to and the date and time of the referral.

9o For example in the UK the system of exchange control is a function of the Treasury delegated to the Bank of England. Hence, the Bank of England is independent in the conduct of monetary policy but is dependent in the conduct of exchange rate policy.

$91 \quad$ Lastra (n 6) 54 .

92 IMF Statistics Department, 'Balance of Payments Manual', 6th edition (2009) $111<w w w$. imf.org/external/pubs/ft/bop/2007/pdf/bpm6.pdf > accessed 21 October 2021. 
In a recent study on foreign exchange reserves, Goldberg and others explained the official actions taken by central banks in order to influence exchange rates through the accumulation or selling of foreign exchange reserves:

consider a country that is running a balance of payments deficit - meaning that cash outflows exceed inflows on all transactions between that country and the rest of the world. To avoid a depreciation of the currency, the central bank can sell foreign exchange reserves and buy up the excess supply of the country's currency. Alternatively, in a balance of payments surplus environment, a central bank can avoid a currency appreciation stemming from excess demand for the country's currency by selling domestic currency and accumulating foreign exchange reserves. ${ }^{93}$

Reserve assets can be classified into seven main categories: monetary gold (gold bullions), Special Drawing Rights (SDR) holdings (IMF reserve assets), reserve position in the IMF, currency and deposits, securities (including debt and equity securities), financial derivatives, and other claims (loans and other financial instruments). ${ }^{94}$ These categories qualify as reserve assets because they are readily available in unconditional form to the monetary authorities. To be readily available the country's reserve assets must be liquid and denominated in a convertible currency.

The management of a country's foreign reserve assets is usually entrusted with the central bank or relevant monetary authority and is part of the foreign exchange policy dictated by the government. ${ }^{95}$ For example, in the US, the Exchange Stabilisation Fund (ESF) of the United States Treasury was established by the Gold Reserve Act of 1934 to contribute to the US dollar exchange rate stability. The ESF operates under the Federal Reserve Bank of New York in its capacity as fiscal agent for the Treasury. ${ }^{96}$ In UK, the Exchange Equalisation Account (EEA) was created in 1932 to make available a fund that can be used to

93 Linda Goldberg, Cindy E Hull and Sarah Stein, 'Do Industrialized Countries Hold the Right Foreign Exchange Reserves?' (2013) 19(1) Current Issues in Economics and Finance $<$ www.newyorkfed.org/research/current_issues/ci19-1.html> accessed 21 October 2021.

94 ibid $113-115$. The SDR holdings and the reserve position in the IMF only apply as reserve assets for the Fund's members.

95 As noted by Goldberg and others, 'Most often these reserves are held by central banks, although in some cases they may be held by finance ministries or sovereign wealth funds'. Linda Goldberg, Cindy E Hull and Sarah Stein (n 93) 1.

96 Federal Reserve Bank of New York, 'Exchange Stabilization Fund' (Fedpoint, May 2007) <www.newyorkfed.org/aboutthefed/fedpoint/fed14.html> accessed 21 October 2021. 
regulate the pound sterling exchange rate stability. The EEA is under the control of the Treasury, which appoints the Bank of England as its agent to manage the reserve assets under the EEA. ${ }^{97}$ In Switzerland, the Governing Board of the Swiss National Bank (SNB) decides on the composition of the reserve assets and manages them in order to fulfil the SNB statutory mandate. ${ }^{98}$ In the last two decades, the use of reserve assets for exchange rate intervention purposes has been very rare in US and UK. ${ }^{99}$ However, Switzerland has been more active in the foreign exchange market with the use of official foreign exchange intervention mechanisms to battle the appreciation of the Swiss franc. ${ }^{100}$

A relevant consideration with regard to foreign reserve assets - or reserve assets held abroad - is the immunities of central banks. The main reason for this is that, within their respective jurisdictions states decide on the level of immunities they provide to their agencies, such as the central bank. However, outside their jurisdictions, states cannot grant immunities to its agents or dependencies. Consequently, the distinction between activities and assets performed and held by central banks for commercial or non-commercial

97 HM Treasury, 'Management of the Official Reserves' < https://assets.publishing.service. gov.uk/government/uploads/system/uploads/attachment_data/file/236352/management_of_the_official_reserves_2013_14.pdf> accessed 21 October 2021.

98 Federal Act of 3 October 2003 on the Swiss National Bank (National Bank Act, NBA) Art 5 and Art 46 <www.admin.ch/opc/en/classified-compilation/20021117/index.html> accessed 21 October 2021.

99 With the exception of the collaborative interventions in foreign exchange markets by the US and the UK together with other countries to support the value of the euro in 2000 and the Japanese yen in 2011.

100 In March 2009 the SNB started with a series of interventions in the foreign exchange market to prevent the appreciation of the Swiss franc. Later, in September 2011, the SNB pegged its minimum exchange rate at 1.20 Swiss franc per euro arguing that 'The current massive overvaluation of the Swiss franc poses an acute threat to the Swiss economy and carries the risk of a deflationary development'. After almost four years of maintaining the peg the SNB discontinued the minimum exchange rate and lowered the interest rate into negative territory considering that 'divergences between the monetary policies of the major currency areas have increased significantly ... The euro has depreciated considerably against the US dollar and this, in turn, has caused the Swiss franc to weaken against the US dollar. In these circumstances, the SNB concluded that enforcing and maintaining the minimum exchange rate for the Swiss franc against the euro is no longer justified'. Swiss National Bank, Annual Reports (2000-2009), <www.snb.ch/en/iabout/ pub/annrep/id/pub_annrep> (accessed 21 October 2021); Swiss National Bank, Swiss National Bank Sets Minimum Exchange Rate at CHF 1.20 per Euro (2011), <www.snb.ch/en/ $\mathrm{mmr} /$ reference/pre_201109o6/source/pre_201109o6.en.pdf> (accessed 21 October 2021); Swiss National Bank, Swiss National Bank discontinues minimum exchange rate and lowers interest rate to $-0.75 \%$ (2015), www.snb.ch/en/mmr/reference/pre_20150115/source/pre _20150115.en.pdf (accessed 21 October 2021). 
purposes acquires relevance at this point. ${ }^{101}$ As stated before, central banks conduct both commercial and non-commercial activities. In the performance of non-commercial or public functions such as monetary policy and exchange rate policy central banks usually have sovereign immunity.

As noted by Lastra, the theory of sovereign immunity has evolved over time and nowadays "The new theory of sovereign immunity restricts immunity under certain circumstances, namely when the sovereign engages in acts of a private law or commercial nature' ${ }^{102}$ Nonetheless, Lastra also remarked that central banks and monetary authorities enjoy a distinctive treatment that protect their foreign property from judicial remedies with the presumption that most central bank properties and activities are of a non-commercial nature. ${ }^{103}$ This differential treatment is enshrined in the text of domestic laws such as, the State Immunity Act (SIA) of 1978 in the UK, ${ }^{104}$ the Foreign Sovereign Immunities Act (FSIA) of 1976 in the US 105 and is also considered by an international treaty, the United Nations Convention on Jurisdictional Immunities of States and Their Property (UNCJIS) of 2004. ${ }^{106}$ The presumption of the noncommercial nature of central bank activities and properties is recognised in recent cases like NML Capital, Ltd. v Banco Central de la Republica Argentina. ${ }^{107}$ As remarked by Proctor, in order to determine whether a particular act is of sovereign or commercial character, it 'is the nature of the particular activity, rather than the underlying purpose which will be relevant.'108

\footnotetext{
101 The law of the state immunity differentiates the acts of the sovereigns (acta jure imperii) from acts of a commercial nature (actajure gestionis). The theoretical debate of the law of state immunity is discussed extensively in Hazel Fox and Philippa Webb, The Law of State Immunity (3rd edn, oup 2013).

102 Lastra (n 6) 96-100.

103 ibid.

104 State Immunity Act 1978.

105 Foreign Sovereign Immunities Act of 1976, Pub L 94-583, 9o Stat 2891 (1976) <www.gpo. gov/fdsys/pkg/STATUTE-9o/pdf/STATUTE-9o-Pg2891.pdf> accessed 21 October 2021.

106 The UNCJIS was adopted in December 2004 during the 65th plenary meeting of the General Assembly by resolution A/59/38 but has not been ratified by enough states in order to become effective. United Nations Treaty Collection, '13. United Nations Convention on Jurisdictional Immunities of States and Their Property' <https://treat ies.un.org/Pages/ViewDetails.aspx?src=IND\&mtdsg_no=III-13\&chapter=3\&lang=en > accessed 21 October 2021.

107 NML Capital, Ltd. v Banco Central de la Republica Argentina (n 9).

108 Proctor (n 8) 574. Proctor also provides a detailed analysis of the recent cases dealing with the status of monetary institutions before domestic courts and the correspondent procedural immunities. See Proctor (n 8) 572-585.
} 
This chapter describes the fundamental role that domestic and regional institutional arrangements have in the promotion of monetary stability. The central banks or relevant monetary authorities are at the centre of this institutional framework both in the pursuit of price stability (internal dimension) and exchange rate stability (external dimension). This chapter also remarks that despite these internal and external dimensions which are interrelated and are better achieved by coordinated actions and policies, they can also present conflicting objectives in the medium and long term.

Beyond the possible conflict between price stability and exchange rate stability, central banks have expanded both their objectives and instruments in the pursuit of stable monetary systems and have also demonstrated themselves to be unique institutions poised to respond to crisis situations such as the GFC. Such unique features are their delegated mandate objectives, instrument independence and accountability, which has allowed them to adapt to changing economic environments and keep their crucial role in the monetary system. As remarked by Arner, 'While central banks adhere to domestic concerns and act autonomously, their independence allows the growth of international cooperation that is increasingly vital to support a state's economic viability'. ${ }^{109}$ Notwithstanding the central banks' crucial role in global crisis management scenarios, as remarked in this chapter, they are still institutions of state that are constrained by their domestic goals and mandate. Hence, when it comes to central banks assuming international commitments or engaging with enhanced monetary policy cooperation it rests on unpredictable soft-law commitments that are decided on a case by case situation.

Consequently, it can be argued that under the current circumstances the obligations to do homework promoted by the emerging doctrine of Common Concern in relation to monetary stability are constrained to domestic and regional objectives that do not consider the global dimension. Hence, the aim of Common Concern, if it develops as a principle of law, is to reinforce the role of states as main providers of GPGs not only locally but also globally. As asserted by Cottier, enhanced and shared responsibilities among states beyond existing rights and obligations under international law are of the essence of the legal principle of Common Concern of Humankind. ${ }^{110}$

\footnotetext{
109 Arner and others (n 14) 21.

110 Cottier, 'The Principle of Common Concern of Humankind' (n 1) 84.
} 
These new responsibilities at the domestic level - triggered by the principle of Common Concern and assisted by the multilevel governance theory ${ }^{111}$ may involve an expansion on the mandate goals of central banks to include global stability considerations while deciding domestic policy action. Also, going further, to provide central banks with the possibility to assume international commitments for special situations using as a trigger the Common Concern threshold of the threat to peace, stability and welfare applied to monetary stability. For example, in a liquidity crisis scenario the states which are issuers of reserve currencies may have a commitment to establish bilateral or multilateral swap lines (through their respective central banks) with the central banks of the countries in need of liquidity. Hence, moving from a discretional attribute of central banks to a commitment activated by the principle of Common Concern (resorting to the principle of shared but differentiated responsibility). Furthermore, the emerging doctrine of Common Concern demands increased transparency and accountability. Hence, the implementation of these enhanced obligations of central banks will also involve renewed efforts on transparency, information sharing and accountability, as with more responsibility comes more accountability.

111 For a description of the multilevel governance theory see chapter 3 of this book. 